Erratum

\title{
Erratum: Zhang, Y., et al. Interface-Active Metal Organic Frameworks for Knoevenagel Condensations in Water. Catalysts 2018, 8, 315
}

\section{Catalysts Editorial Office}

MDPI, St. Alban-Anlage 66, 4052 Basel, Switzerland; catalysts@mdpi.com

After the publication of the research paper, stated in the title above [1], the Catalysts editorial office noticed errors, and wish to make corrections. Some spaces should have been added between words. See the following examples:

In the second line of the Abstract, "developefficient" should be "develop efficient";

In the Introduction, (in the first paragraph, line five) "toincrease" should be "to increase"; and "itresults" should be "it results".

We apologize for any inconvenience caused to the readers by these changes. The changes do not affect the scientific results. The original manuscript [1] will be updated, and will remain online on the article webpage, with a reference to this erratum.

\section{Reference}

1. Zhang, Y.; Zhang, X.; Bai, R.; Hou, X.; Li, J. Interface-Active Metal Organic Frameworks for Knoevenagel Condensations in Water. Catalysts 2018, 8, 315. [CrossRef]

(C) 2018 by the author. Licensee MDPI, Basel, Switzerland. This article is an open access article distributed under the terms and conditions of the Creative Commons Attribution (CC BY) license (http:/ / creativecommons.org/licenses/by/4.0/). 